\title{
Influence of Medetomidine on Acid-base Balance and Urine Excretion in Goats
}

\author{
By M. Raekallio ${ }^{1}$, M. Hackzell ${ }^{2}$ and L. Eriksson ${ }^{2}$ \\ ${ }^{1}$ Department of Clinical Sciences and ${ }^{2}$ Department of Physiology, College of Veterinary Medicine, Helsinki, \\ Finland.
}

\begin{abstract}
Raekallio M., M. Hackzell and L. Eriksson: Influence of medetomidine on acid-base balance and urine excretion in goats. Acta vet. scand. 1994, 35, 283-288. - Seven goats were given medetomidine $5 \mu \mathrm{g} / \mathrm{kg}$ as an iv bolus injection. Venous blood samples were taken repeatedly and urine was collected continuously via a catheter up to $7 \mathrm{~h}$ after the injection.

Medetomidine caused deep clinical sedation. Base excess, $\mathrm{pH}$ and $\mathrm{PCO}_{2}$ in venous blood rose after medetomidine administration. There were no significant changes in plasma concentrations of sodium, calcium, magnesium, creatinine or osmolality, whereas potassium and bicarbonate concentrations increased, and phosphate and chloride decreased. Medetomidine increased plasma glucose concentration, and in 4 of 7 goats glucose could also be detected in urine. Medetomidine did not influence urine flow rate, free water clearance, bicarbonate and phosphate excretion or $\mathrm{pH}$, but renal chloride, sodium, potassium, calcium, magnesium and creatinine excretion were reduced.

The results suggest that the metabolic alkalosis recorded after medetomidine administration is not caused by increased renal acid excretion.
\end{abstract}

metabolic alkalosis; base excess; bicarbonate.

\section{Introduction}

The $\alpha_{2}$-adrenoceptor agonist detomidine causes an increase in base excess in horses, which indicates metabolic alkalosis (Raekallio et al. 1990). $\alpha_{2}$-Adrenoceptor agonists are also known to induce diuresis and natriuresis ( $\mathrm{Gel}$ lai 1990), but there seem to be differences between species in the $\alpha_{2}$-adrenoceptor modulation of vasopressin action (Gellai 1990, Brooks et al. 1991). Renal $\alpha_{2}$-adrenoceptors may also influence urinary bicarbonate and chloride excretion and thus affect the acidbase balance.

The purpose of the present study was to determine whether the base excess increases after administration of another $\alpha_{2}$-adrenoceptor agonist, medetomidine, in goats and whether increased renal acid excretion is involved in the development of this metabolic alkalosis.

\section{Materials and methods}

Seven adult female goats (weight $38-57.5 \mathrm{~kg}$, mean $49.0 \mathrm{~kg}$ ) were given medetomidine $5 \mu \mathrm{g} / \mathrm{kg}$ iv as a bolus injection. The goats were maintained in metabolic cages during the experiment, and they were supported with slings to keep them in a standing position during sedation.

Venous blood samples were collected from cannulae inserted into both jugular veins. The cannulae were flushed with sodium citrate solution after samplings. Venous blood was taken into heparinized syringes (Arterial 
Blood Sampler, QS90 ${ }^{\mathrm{TM}}$, Radiometer, Copenhagen, Denmark) 30min before and 10, 20, $30 \mathrm{~min}$ after treatment, and every $15 \mathrm{~min}$ until $75 \mathrm{~min}$, thereafter every $30 \mathrm{~min}$ until $6 \mathrm{~h} 45 \mathrm{~min}$. The samples were chilled immediately and stored in melting ice until analyzed by an auto-analyzer (ABL 300, Radiometer, Copenhagen, Denmark) within $30 \mathrm{~min}$ of collection. Venous $\mathrm{PCO}_{2}, \mathrm{pH}$, base excess, and bicarbonate concentration were measured.

Venous blood was also collected into glass tubes containing lithium heparin $30 \mathrm{~min}$ before administration of medetomidine, $15 \mathrm{~min}$ after it, and every 30 min thereafter until $6 \mathrm{~h}$ $45 \mathrm{~min}$. The plasma was separated by centrifugation and frozen until sodium, potassium, chloride, calcium, magnesium, phosphate, creatinine and glucose concentrations were analyzed.

The urinary bladder was catheterised with a Foley catheter and emptied 40min before medetomidine injection. Urine was collected continuously into a measuring glass which was emptied $20 \mathrm{~min}$ before treatment, at the time of treatment, and thereafter every $30 \mathrm{~min}$ until $7 \mathrm{~h}$. Urine $\mathrm{pH}$ and volume were measured immediately. The urine was stored at $-20^{\circ} \mathrm{C}$ until determination of sodium, potassium, calcium, magnesium, phosphate, creatinine, and glucose concentrations and osmolality was carried out. In addition, bicarbonate and chloride concentrations were analyzed from the urine samples of four goats. These samples were stored frozen under liquid paraffin until analyzed.

Plasma and urine sodium and potassium concentrations were analyzed by flame photometry (Corning 480 Flame Photometer, Ciba Corning Diagnostics, Halstead, Essex, England), and calcium and magnesium by atomic absorption spectrophotometry (Perkin-Elmer 2380, Perkin-Elmer Corporation, Norwalk, Connecticut, USA). Plasma and urine phos- phate concentrations were analyzed by spectrophotometry (Weissman \& Pileggi 1974; Perkin-Elmer Spectrophotometer Coleman 55, Coleman Instruments, Division of PerkinElmer Corporation, Oakbrook, Illinois, USA) and creatinine by Jaffe's reaction ( $\mathrm{Fa}$ biny \& Ertingshausen 1971) using an autoanalyzer (Kone Specific Selective Chemistry Analyzer, Kone Corporation, Espoo, Finland). Plasma chloride was analyzed by direct potentiometry (Kone Microlyte, Kone Corporation, Espoo, Finland) and glucose by an autoanalyzer using the enzymatic colorimetric method (Trinder 1969). Test strips (Glukotest, Boehringer Mannheim GmbH, Mannheim, Germany) were used to check urine for glucose. Urine osmolality was measured by the freezing point method (Osmette A, Precision Systems, Inc., Sudbury, Massachusetts, USA). Urine chloride was measured by conductiometric titrating (925 Corning Chloride Analyzer, Corning Medical and Scientific Co., Halstead, Essex, England) and $\mathrm{HCO}_{3}$ by the carbon dioxide (CARB) method (Menson et al. 1974) for the ACA analyzer (Du Pont ACA IV, Du Pont Company, Clinical and Instrument Systems Division, Wilmington, Delaware, USA).

The data were analyzed using the analysis of variance for repeated measurements. If differences were observed, Dunnett's 2-tailed t-test was used to compare individual time points with pretreatment levels. Statistical significance was considered at $\mathrm{P}<0.05$.

\section{Results}

All the goats showed signs of deep clinical sedation after administration of medetomidine. They stood up 25 to $95 \mathrm{~min}$ after the injection. Base excess and blood $\mathrm{pH}$ increased significantly, the average of both reaching their maximums $60 \mathrm{~min}$ after medetomidine injection (Fig. 1). Venous $\mathrm{PCO} 2$ was significantly 


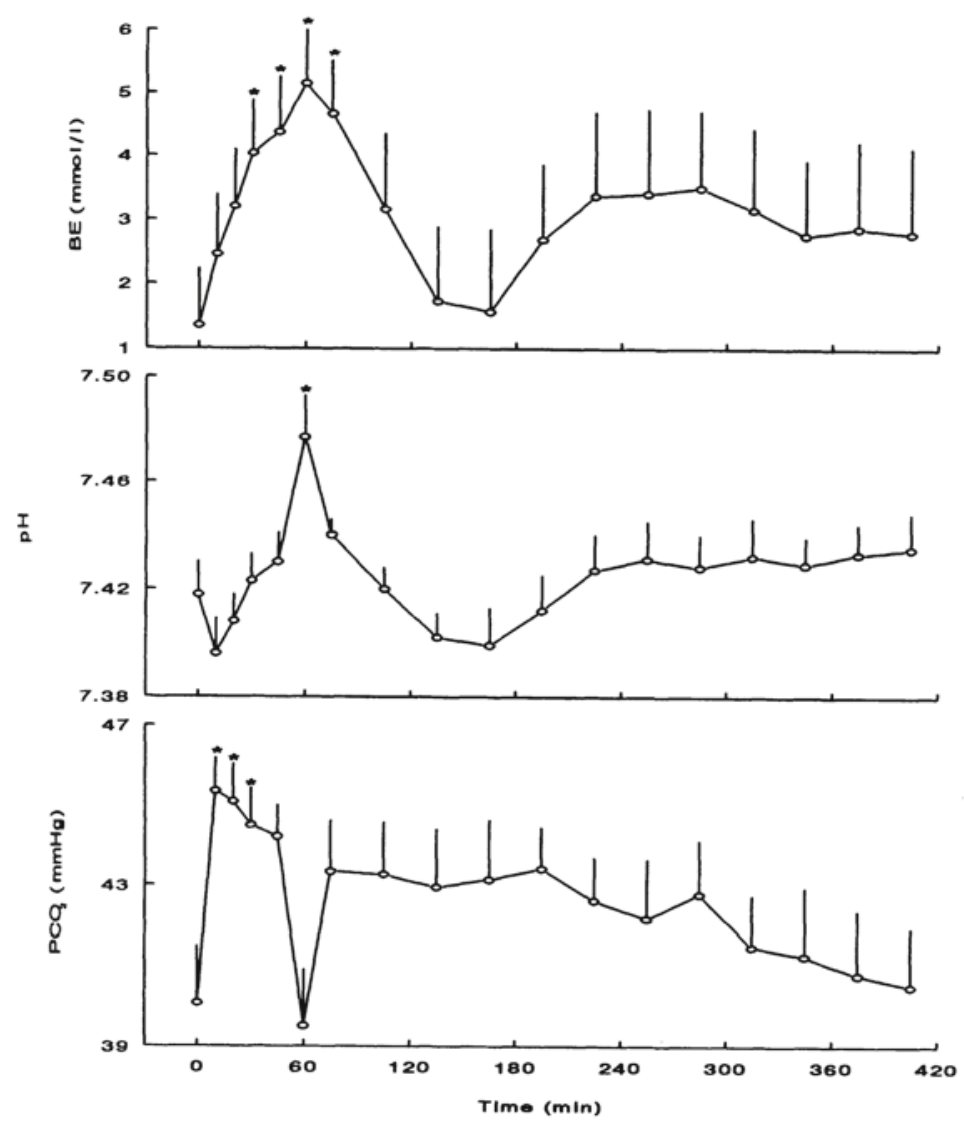

Figure 1. Means $\pm \mathrm{SEM}$ of venous base excess $(\mathrm{BE}, \mathrm{mmol} / \mathrm{l}), \mathrm{pH}$ and partial carbon dioxide pressure $\left(\mathrm{PCO}_{2}\right.$, $\mathrm{mmHg})$ in goats $(\mathrm{n}=7)$ after iv administration of medetomidine $(5 \mu \mathrm{g} / \mathrm{kg})$.

* significantly different from baseline $(\mathrm{p}<0.05)$.

higher than before medication in samples taken 10 to $30 \mathrm{~min}$ after medetomidine administration (Fig. 1), and venous bicarbonate concentration was increased 20 to 75 and $285 \mathrm{~min}$ after medetomidine.

Medetomidine did not influence significantly urine $\mathrm{pH}$, bicarbonate or phosphate excretion. Renal chloride excretion was significantly decreased $135 \mathrm{~min}$ after medetomidine injection (Fig. 2). Medetomidine reduced also renal sodium, potassium, calcium, magnesium and creatinine excretion, but flow rate and free water clearance were not altered.

Plasma sodium, calcium, magnesium, and creatinine concentrations and osmolality did not change significantly. Plasma potassium concentration was significantly increased 45min after medetomidine injection (Fig. 3), but the initial concentration was lower than the normal reference values (Kaneko 1989), and the highest concentrations did not exceed them. Plasma phosphate concentration was 


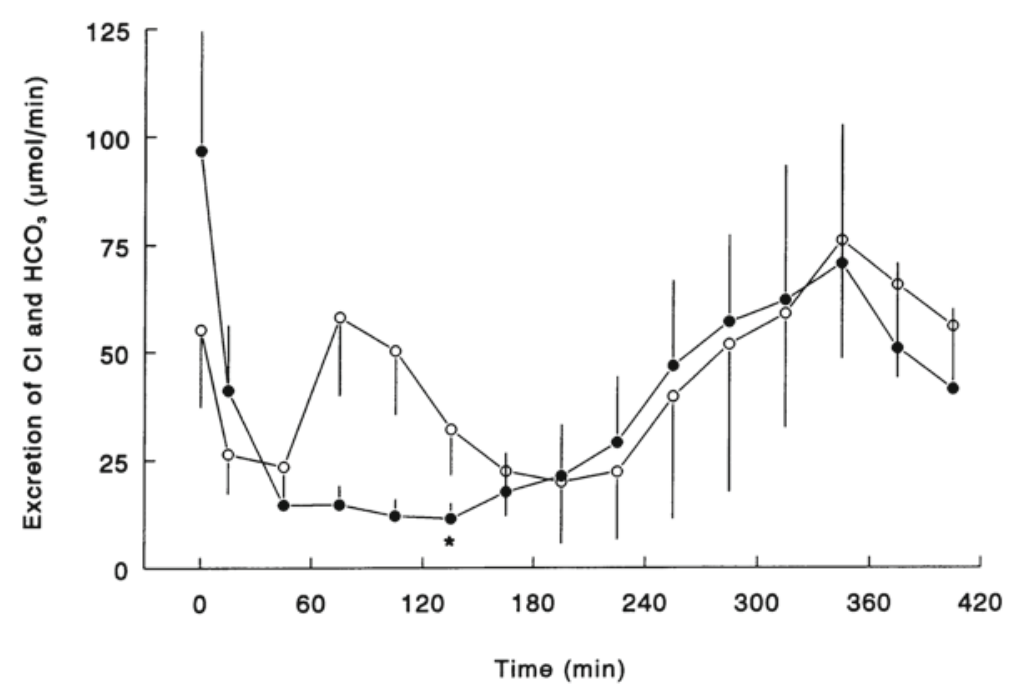

Figure 2. Means \pm SEM of excretion of chloride $(\bullet)$ and bicarbonate $(\mathrm{o})(\mu \mathrm{mol} / \mathrm{min})$, in goats $(\mathrm{n}=4)$ after iv administration of medetomidine $(5 \mu \mathrm{g} / \mathrm{kg})$.

* significantly different from baseline $(\mathrm{p}<0.05)$.

significantly reduced at $135 \mathrm{~min}$, and plasma chloride concentration at $105 \mathrm{~min}$ after medetomidine injection (Fig. 3).

Plasma glucose concentration increased significantly from $3.6 \pm 0.5$ to $8.9 \pm 1.9 \mathrm{mmol} / \mathrm{l}$; peak concentration was reached $75 \mathrm{~min}$ after medetomidine injection. In 4 of 7 goats glucose could also be detected in urine during the high plasma concentrations.

\section{Discussion}

In many species, $\alpha_{2}$-adrenoceptor agonists have been found to induce water diuresis and natriuresis (Gasthuys et al. 1987, Gellai 1990, Brooks et al. 1991). Our findings in goats did not agree with these reports. Instead, a decrease was observed in renal sodium and potassium excretion, which confirmed the antinatriuretic effect of medetomidine reported earlier in this species (Kokkonen 1992). The detectable urine glucose concentrations in several goats and the marked hyperglycaemia caused by medetomidine were analogous to the findings in horses after detomidine administration (Gasthuys et al. 1987).

In the present study, the goats had relatively high urine bicarbonate concentrations both before and after drug administration. The alkaline urine, high in bicarbonate, is typical of herbivores due to the accumulation of bicarbonate ions when organic salts of feed are metabolized (Houpt 1993). In humans, ammonia and phosphate are the two basic urinary buffers, and bicarbonate is not detected in the urine in notable quantities before the blood bicarbonate concentration is around 26 mmol/l (Sabatini \& Kurtzman 1989).

Acidosis was not observed after administration of medetomidine in spite of the increased venous $\mathrm{PCO}_{2}$. On the contrary, medetomidine increased base excess and elevated blood $\mathrm{pH}$ in goats as detomidine did in horses (Raekal- 


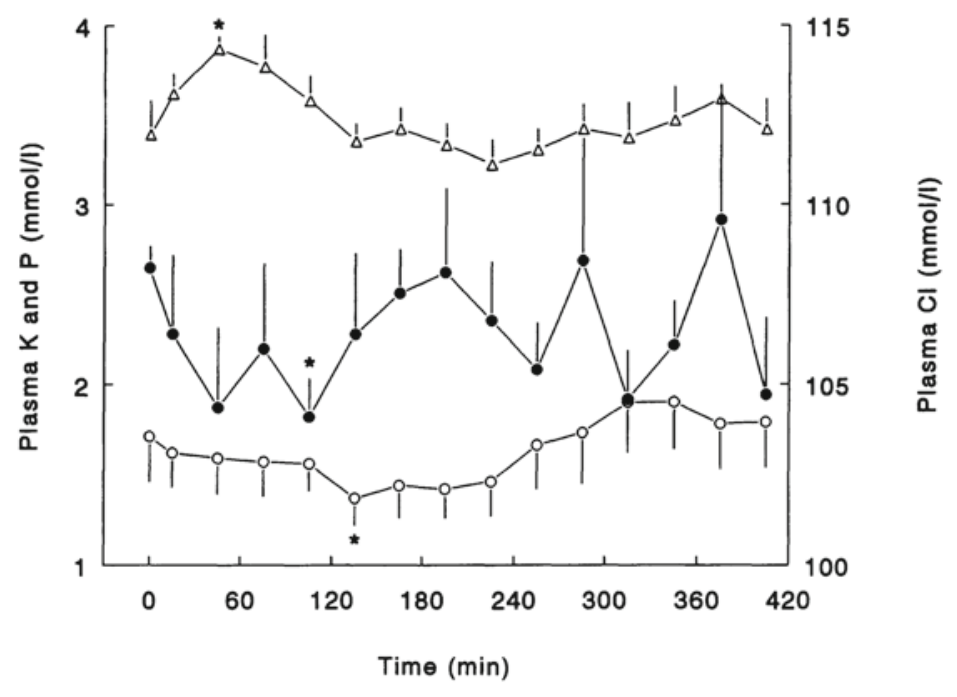

Figure 3. Means \pm SEM of plasma potassium $(\triangle)$, phosphate $(O)$ and chloride $(\bullet)$ concentrations $(\mathrm{mmol} / \mathrm{l})$ in goats $(\mathrm{n}=7)$ after iv administration of medetomidine $(5 \mu \mathrm{g} / \mathrm{kg})$.

* significantly different from baseline $(\mathrm{p}<0.05)$.

lio et al. 1990), indicating metabolic alkalosis. However, no changes were detected in urine $\mathrm{pH}$ or bicarbonate excretion. Therefore, changes in renal function are not a likely reason for the medetomidine induced alkalosis. The intestinal secretions contain high concentrations of bicarbonate. An $\alpha_{2}$-adrenergic mechanism is involved in the inhibition of acid-induced duodenal bicarbonate secretion in rats, although it is not known whether the neurogenic mechanism acts directly on the secreting epithelial cells or on enteric secretomotor neurons (Jönson et al. 1991). Thus a change in intestinal bicarbonate secretion might be a contributory factor of the metabolic alkalosis seen after administration of medetomidine in goats. In addition, $\alpha_{2}$-adrenergic stimulation of intestinal epithelial cells is known to promote fluid and electrolyte absorption (Fedorak et al. 1985), which might influence also bicarbonate absorption.
It is concluded that the metabolic alkalosis detected after medetomidine administration is not likely to be caused by increased urinary acid excretion.

\section{Acknowledgements}

This study was supported by the Finnish National Research Council for Medical Sciences (Project No 1091008).

\section{References}

Brooks DP, Gellai M, DePalma PD, Edwards RM: Modulation of vasopressin antidiuretic action by $\alpha_{2}$-adrenoceptors is species specific. Amer. J. Physiol. 1991, 261, R1242-R1246.

Fabiny DL, Ertingshausen G: Automated reactionrate method for determination of serum creatinine with the CentrifiChem. Clin. Chem. 1971, 17, 696-700.

Fedorak RN, Field M, Chang EB: Treatment of diabetic diarrhea with clonidine. Ann. Int. Med. 1985, 102, 197-199. 
Gasthuys F, Terpstra P, van den Hende C, De Moor $A$ : Hyperglycaemia and diuresis during sedation with detomidine in the horse. J. vet. Med. 1987, A 34, 641-648.

Gellai M: Modulation of vasopressin antidiuretic action by renal $\alpha_{2}$-adrenoceptors. Amer. J. physiol. 1990, 259, F1-F8.

Houpt TR: Acid-base balance. In: (Eds) Swenson MJ, Reece WO: Dukes' Physiology of Domestic Animals, 11th ed. Comstock Publishing Associates, Ithaca. 1993, pp. 604-615.

Jönson C, Hamlet A, Fändriks L: Hypovolemia inhibits acid-induced alkaline transport in the rat duodenum via an alpha-2 adrenergic mechanism. Acta physiol. scand. 1991, 142, 367-373.

Kaneko JJ: Appendixes. In: (Ed) Kaneko JJ: Clinical Biochemistry of Domestic Animals, 4th edn. Academic Press Inc., San Diego. Ed Kaneko JJ. 1989, pp. 877-901.

Kokkonen U-M: Renal action of medetomidine, an alpha-2-agonist, and atipamezole, an alpha-2-antagonist, in the goat. Acta physiol. scand. 1992, 146, Suppl. 608, 188.

Menson RC, Narayanswamy V, Bussian RW, Adams TH: A kinetic method for determination of $\mathrm{CO}_{2}$ in biological fluids. Clin. Chem. 1974, 20, 872.

Raekallio M, Vainio $O$, Karjalainen J: The influence of atipamezole on the cardiovascular effects of detomidine in horses. J. Ass. vet. Anaesth. 1990, 17, 50-53.

Sabatini S, Kurtzman NA: Overall acid-base regulation by the kidney. In: (Eds) Seldin DW \& Giebisch G. The regulation of acid-base balance, Raven Press, New York. 1989, pp. 185-210.
Trinder P: Determination of glucose in blood using glucose oxidase with an alternative oxygen acceptor. Ann. Clin. biochem. 1969, 6, 24-27.

Weissman N, Pileggi VJ: Determination of Inorganic Phosphorus. In: (Eds) Henry RJ, Cannon DC, Winkelman JW. Clinical Chemistry, Principles and Technics, 2nd ed. Harper \& Row, Publishers, Inc., Maryland. 1974, pp. 723-727.

\section{Sammanfattning}

Effekten av medetomidin på syra-basbalans och urinutsöndring hos get.

Medetomidin gavs till sju getter som intravenös engångsdos av $5 \mu \mathrm{g} / \mathrm{kg}$. Venösa blodprov togs upprepande gånger och urin samlades kontinuerligt via kateter ända till 7 timmar efter injektionen.

Medetomidin framkallade djup klinisk sedation. Basöverflöd, $\mathrm{pH}$ och $\mathrm{PCO}_{2}$ i venöst blod ökade efter medetomidin injektionen. Plasmans koncentration av natrium, kalcium, magnesium, kreatinin samt osmolalitet ändrade sig inte signifikant, medan koncentration av kalium och bikarbonat ökade och fosfat och klorid minskade. Medetomidin ökade plasmans glukoskoncentration och i fyra av de sju getterna kunde glukos upptäckas även i urin. Medetomidin inverkade inte på urinflöde, "fritt vatten-clearance «, utsöndring av bikarbonat och fosfat eller $\mathrm{pH}$, men utsöndring av klorid, natrium, kalium, kalcium, magnesium och kreatinin minskade.

Resultaten tyder på, att den observerade metaboliska alkalosen efter medetomidin injektionen med all sannolikhet inte förorsakades av ökad syrautsöndring i urin.

(Received April 6, 1994; accepted June 9, 1994).

Reprints may be requested from: M. Raekallio, Department of Clinical Sciences, College of Veterinary Medicine, P. O. Box 6, SF-00581 Helsinki, Finland. 